\title{
THE EFFECT OF WATER EXTRACTS FROM WINTER SAVORY ON BLACK BEAN APHID MORTALITY
}

\author{
Milena Rusin'1, Janina Gospodarek' ${ }^{1}$ Barbara Biniaś ${ }^{1}$ \\ 1 Department of Agricultural Environment Protection, University of Agriculture, al. Mickiewicza 21, 31-120 \\ Kraków, Poland, e-mail: milena_rusin@wp.pl
}

Received: 2015.11.16

Accepted: 2015.12.09

Published: 2016.01.06

\begin{abstract}
The aim of this study was to determine the effect of water extracts prepared from fresh and dry matter of winter savory (Satureja montana L.) on mortality of wingless females and larvae of black bean aphid (Aphis fabae Scop.). The experiment was conducted in the laboratory, in six replicates. Dry extracts were prepared at concentration of $2 \%, 5 \%$ and $10 \%$, while the fresh plant at concentration of $10 \%, 20 \%$ and $30 \%$. Stomach poisoning of extracts was determined by soaking broad bean leaves in the respective solutions, and then determining mortality of wingless female and larvae feeding on leaves thus prepared at 12 hour intervals. The results of the experiment showed that the extract prepared from dry matter at the highest concentration $(10 \%)$, as well as the extracts from fresh matter at concentration of $20 \%$ and $30 \%$ contributed to an increase in mortality of wingless female of black bean aphid. Meanwhile, extracts prepared from both dry and fresh matter at two highest concentrations caused an increase in mortality of larvae of this pest. Furthermore, with increasing concentrations of analysed extracts prepared from both fresh and dry matter of winter savory, their negative effect on wingless females and larvae usually increase.
\end{abstract}

Keywords: water extracts, black bean aphid (Aphis fabae Scop.), winter savory (Satureja montana L.), biological control.

\section{INTRODUCTION}

Black bean aphid (Aphis fabae Scop.) is one of the most important pests of many crops such as: broad bean, field bean, beets or tomatoes. Yield losses caused by feeding of this pest can reach above 50\% [Hansen et al. 2007]. Both the adults and larvae puncture leaves, stems, flowers and young pods of plant and suck their juices cell, which leads to yellowing plants, their withering and dying. In addition, these pests are vectors of viral diseases and contributes to reduce the protein content in leaves [Shannag 2007].

Application of appropriate insecticides is one of the most common method of plant protection against aphids. However, these compounds may adversely affect all elements of the environment and pose a potential health and life risk for humans and animals [Tscharntke et al. 2005]. In addition, pests are more often able to immunize to active substances contained in insecticides, thereby reducing their effectiveness [Nauen and Denholm 2005, Wang et al. 2007]. Therefore non-chemical methods, which may equally limit feeding of aphids on crops, are more often sought. One of biological plant protection methods, which is becoming increasingly important, is the use of plant extracts that may reduce pests feeding effectively. The extracts are prepared from fresh or dried parts of herbaceous plant [Dankowska and Bendowska 2006, Wawrzyniak 2009, Deletre et al. 2015].

Winter savory (Satureja montana L.) is herbaceous plant belonging to the Lamiaceae family, which has many uses. It is used mainly as a spice, because of its intense aroma. It is also used in medicine, because it contains a lot of biologically active substances such as essential oil, triterpenes, tannins or flavonoids [Gniewosz et al. 2009, Silva et al. 2009]. Moreover, it character- 
ized by potent antimicrobial properties [Olasupo et al. 2003, Ćavar et al. 2008, Serrano et al. 2011].

The aim of this study was to determine the effect of water extracts at different concentrations prepared from fresh and dry matter of winter savory on mortality of wingless females and larvae of black bean aphid.

\section{MATERIAL AND METHODS}

The experiment was conducted in the laboratory, in six replicates. Fresh leaves of broad bean, wingless females and larvae of black bean aphid used for the analysis at the end of June 2015 were collected.

Extracts from dry matter (DM) of winter savory were prepared at concentration conventionally adopted as $2 \%, 5 \%$ and $10 \%$ (dried plants + cold double-distilled water in proportions of 2:100, 5:100 and 10:100) and at concentration of $10 \%, 20 \%$ and $30 \%$ for fresh matter (FM) (fresh above-ground parts of plants + cold double-distilled water in proportions of 10:100, 20:100 and 30:100). Extracts were stored at room temperature in the dark over a period of 24 hours. After this period they were filtered through filters paper and immediately used to perform the experiments. The test was conducted in Petri dishes, and as a substrate wet filter paper was used. Broad bean leaves were dipped for 3 seconds in an adequate plant extracts and in distilled water which was a control object, and then dried at room temperature. In each dish one leave of broad bean, suitable for a specific object was placed and then five wingless females of black bean aphid and separately ten larvae were introduced. In determining the effect of extracts prepared from dry and fresh matter of winter savory on aphids, mortality of wingless females and larvae was determined at 12 hour intervals.

The obtained results were then subjected to analysis by STATISTICA 10.0 software. The significance of differences between the means were tested by univariate analysis of variance, and the means were differentiated by Fisher's LSD test at $\alpha=0.05$.

\section{RESULTS AND DISCUSSION}

Among all extracts prepared from dry matter of winter savory used in the experiment only extract at the highest concentration $(30 \%)$ resulted in a significant increase in mortality of wingless female of black bean aphids compared to the control and to the extracts prepared at lower concentrations (with the exception of extract at concentration of 5\% after 48 hours from the setting up the experiment) (Figure 1). This dependence was noted in all terms of observations. After 84 hours this extract caused a total mortality of wingless females, while in the control this parameter reached the level approx. $45 \%$, and in remaining objects was lower than $60 \%$. With increasing concentrations of extracts their negative effect on the tested pests was usually increasing, but as mentioned above, only in the object where the highest concentration of extract was used differences were statistically significant compared to control.

Extract prepared from fresh matter at concentrations of 30\% after 36 hours from the setting up the experiment resulted in a significant increase in mortality of wingless female of black bean aphid

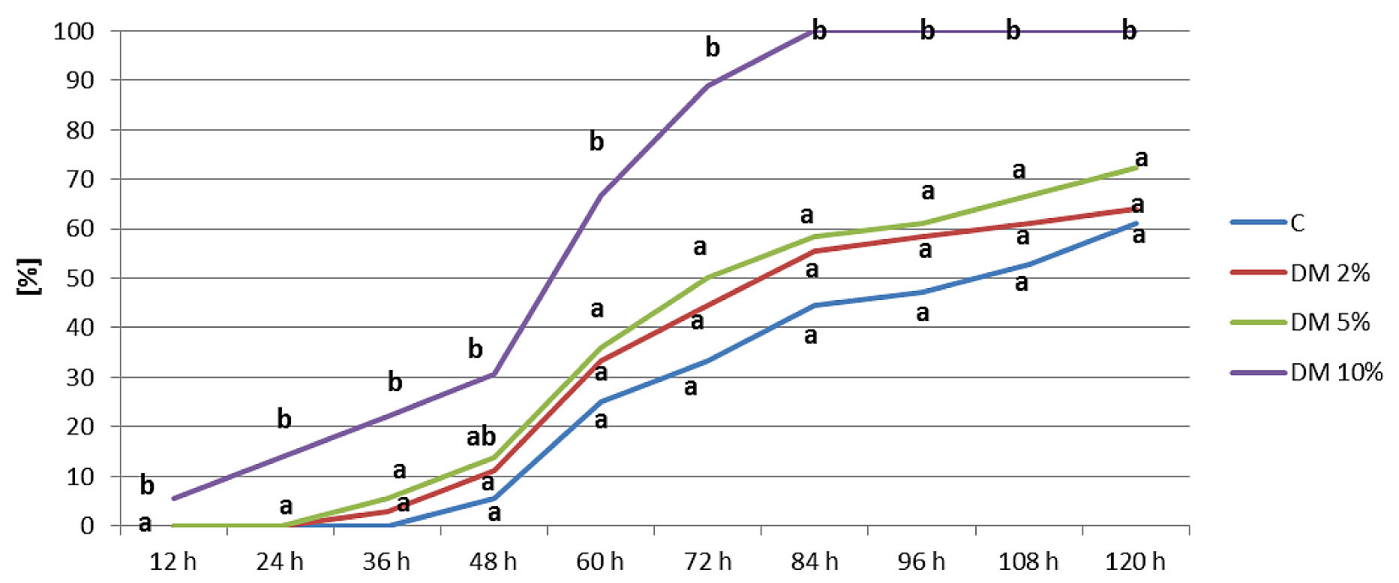

Figure 1. The effect of water extracts prepared from dry matter of winter savory on mortality of wingless females of black bean aphid [\%]. DM - dry matter. Values for individual terms of observations marked by different letters are statistically different $(\alpha=0.05)$ 
compared to the control and the state was maintained until the end of the experiment (Figure 2). Similar regularities were also reported in the case of the extract at concentration of $20 \%$, however, statistically significant differences in relation to the control object only after 72 hours were observed. The extract at concentration of $10 \%$ had no significant effect on the analysed parameter in all terms of observation. After 120 hours the mortality of females in objects where extracts at concentrations of $20 \%$ and $30 \%$ were used, reached up $100 \%$, while in the control was lower nearly by $40 \%$.

Extracts prepared from both dry and fresh matter of winter savory at the highest concentrations (10\% and $30 \%$ respectively) in almost all terms of observations (with the exception of first term in the case of fresh extract) resulted in a significant increase in mortality of black bean aphid larvae compared to the control object (Table 1). Extract prepared from dry matter at concentrations of $5 \%$ after 36 hours also caused a significant increase in mortality of analysed pests, as well as an extract prepared from fresh matter at concentration of $20 \%$ after 48 hours from the setting up the experi- ment. The lowest concentrations of extract, which was used, had no significant effect on the analysed feature. With increasing concentrations of extracts their negative effect on black bean aphid larvae was usually increasing and in many cases the differences between the individual concentrations were statistically significant.

Only a small number of studies have been made to date on the effect of water extract prepared from winter savory on feeding of crop pests. Only Šucur et al. [2015] showed that the extract prepared from dry matter of this plant may contribute to over fourfold increase in mortality of greenhouse whitefly (Trialeurodes vaporariorum Westwood), which can damage many plants grown in greenhouses and polytunnels. Deltere et al. [2015] also found that this extract can be toxic and irritating to Bemisia tabaci Gennadius.

More often, studies regarding the use of essential oils obtained from the winter savory and other plants belonging to Lamiaceae family were conducted. However, essential oils have a much higher concentration of the compounds contained in them than conventional water extracts. Picard

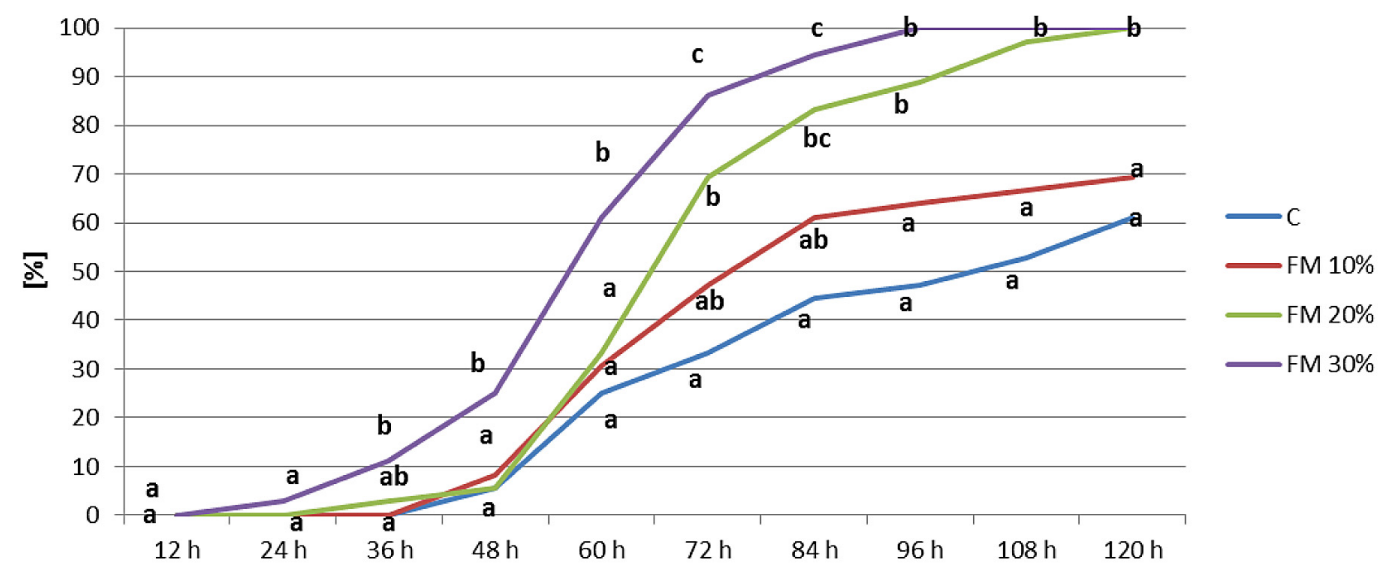

Figure 2. The effect of water extracts prepared from fresh matter of winter savory on mortality of wingless females of black bean aphid [\%]. FM - fresh matter. Values for individual terms of observations marked by different letters are statistically different $(\alpha=0.05)$

Table 1. The effect of water extracts prepared from dry and fresh matter of winter savory on mortality of black bean aphid larvae [\%]. DM - dry matter, FM - fresh matter. Values for individual terms of observations marked by different letters are statistically different $(\alpha=0.05)$

\begin{tabular}{|c|c|c|c|c|c|c|c|c|c|c|}
\hline Object & $12 \mathrm{~h}$ & $24 \mathrm{~h}$ & $36 \mathrm{~h}$ & $48 \mathrm{~h}$ & $60 \mathrm{~h}$ & $72 \mathrm{~h}$ & $84 \mathrm{~h}$ & $96 \mathrm{~h}$ & $108 \mathrm{~h}$ & $120 \mathrm{~h}$ \\
\hline C & $1.7^{\mathrm{a}}$ & $1.7^{\mathrm{a}}$ & $3.3^{\mathrm{a}}$ & $3.3^{\mathrm{a}}$ & $6.7^{\mathrm{a}}$ & $8.3^{\mathrm{a}}$ & $13.3^{\mathrm{a}}$ & $15.0^{\mathrm{a}}$ & $21.7^{\mathrm{a}}$ & $31.7^{\mathrm{a}}$ \\
\hline DM 2\% & $3.3^{\mathrm{a}}$ & $3.3^{\mathrm{a}}$ & $5.0^{\mathrm{a}}$ & $8.3^{\mathrm{a}}$ & $11.7^{\mathrm{a}}$ & $15.0^{\mathrm{a}}$ & $20.0^{\mathrm{a}}$ & $23.3^{\mathrm{a}}$ & $33.3^{\mathrm{a}}$ & $40.0^{\mathrm{a}}$ \\
\hline DM 5\% & $8.3^{\mathrm{ab}}$ & $15.0^{\mathrm{ab}}$ & $18.3^{\mathrm{b}}$ & $25.0^{\mathrm{b}}$ & $31.7^{\mathrm{bc}}$ & $43.3^{\mathrm{c}}$ & $53.3^{\mathrm{bc}}$ & $70.0^{\mathrm{b}}$ & $80.0^{\mathrm{b}}$ & $88.3^{\mathrm{b}}$ \\
\hline DM 10\% & $13.3^{\mathrm{b}}$ & $21.7^{\mathrm{b}}$ & $26.7^{\mathrm{b}}$ & $31.7^{\mathrm{b}}$ & $33.3^{\mathrm{c}}$ & $48.3^{\mathrm{c}}$ & $63.3^{\mathrm{c}}$ & $78.3^{\mathrm{c}}$ & $100.0^{\mathrm{c}}$ & $100.0^{\mathrm{b}}$ \\
\hline FM 10\% & $0.0^{\mathrm{a}}$ & $3.3^{\mathrm{a}}$ & $8.3^{\mathrm{a}}$ & $11.7^{\mathrm{ab}}$ & $13.3^{\mathrm{ab}}$ & $18.3^{\mathrm{ab}}$ & $25.0^{\mathrm{a}}$ & $28.3^{\mathrm{a}}$ & $31.7^{\mathrm{a}}$ & $36.7^{\mathrm{a}}$ \\
\hline FM 20\% & $5.0^{\mathrm{a}}$ & $11.7^{\mathrm{ab}}$ & $13.3^{\mathrm{ab}}$ & $21.7^{\mathrm{b}}$ & $26.7^{\mathrm{b}}$ & $36.7^{\mathrm{b}}$ & $48.3^{\mathrm{b}}$ & $65.0^{\mathrm{b}}$ & $78.3^{\mathrm{b}}$ & $86.7^{\mathrm{b}}$ \\
\hline FM 30\% & $6.7^{\mathrm{ab}}$ & $18.3^{\mathrm{b}}$ & $25.0^{\mathrm{b}}$ & $31.7^{\mathrm{b}}$ & $36.7^{\mathrm{c}}$ & $46.7^{\mathrm{c}}$ & $61.7^{\mathrm{c}}$ & $76.7^{\mathrm{c}}$ & $90.0^{\mathrm{c}}$ & $100.0^{\mathrm{b}}$ \\
\hline
\end{tabular}


et al. [2012] studied the effect of the essential oil obtained from winter savory on the western flower thrips (Frankliniella occidentalis Pergande) feeding. The authors in their studies showed that this substance at concentrations of $0.5 \%$ has a high repellent property against the analysed pest. Maedeh et al. [2011] showed, in turn, that the essential oil from the summer savory is toxic and deterrent for red flour beetle (Tribolium castaneum Herbst), Mediterranean flour moth (Ephestia kuehniella Zell.) and Indianmeal moth (Plodia interpunctella Hübner). Furthermore with increasing concentration of essential oil also the mortality of tested insects increases. Ebadollahi [2011] found that essential oils from summer savory increase mortality of wheat weevil (Sitophilus granaries L.) and rice weevil (Sitophilus oryzae L.). The author also emphasized that the effectiveness of the tested essential oil depends on its concentration, exposure time and the type of plant material. Furthermore, Nottingham [1991] showed that essential oil from this plant has deterrent effect on black bean aphid (Aphis fabae Scop.) and cabbage aphid (Brevicoryne brassicae L.). Popović et al. [2013] found that essential oils from other plants belonging to the Lamiaceae family increase mortality of red flour beetle. They also observed that the chemical composition of used oils has a large impact on their effectiveness.

Adverse effect of the extract and essential oils prepared from winter savory and other plants belonging to the Lamiaceae family on pests feeding was probably due to the fact that they contain much tannin and flavonoid in their chemical composition [Gniewosz et al. 2009, Silva et al. 2009]. Tannins are characterized by a toxic effect against some insects, which is associated with initiation of reactions leading to the formation of large amounts of reactive oxygen forms and with inhibition of the activity of many enzymes. Flavonoids, in turn, are acting as a natural insecticides and fungicides, limiting feeding of pests [Lamparski and Wawrzyniak 2004, Raymond et al. 2011].

\section{CONCLUSIONS}

1. The extract prepared from dry matter at the highest concentration $(10 \%)$, as well as the extracts from fresh matter at concentration of $20 \%$ and $30 \%$ contributed to an increase in mortality of wingless female of black bean aphid.
2. Extracts prepared from both dry and fresh matter at two highest concentrations caused an increased mortality of larvae of analysed pest.

3. With increasing concentrations of analysed extracts prepared from both fresh and dry matter of winter savory, their negative effect on wingless females and larvae usually increase.

\section{Acknowledgements}

The work was financed from designated subsidy to conduct research, development work and related tasks, contributing to the development of young scientists and University of Agriculture $\mathrm{PhD}$ students financed under competition procedure in 2015. No topic 4172.

\section{REFERENCES}

1. Ćavar S., Maksimović M., Šolić M.E., JerkovićMujkić A., Bešta R. 2008. Chemical composition and antioxidant and antimicrobial activity of two Satureja essential oils. Food Chem. 111(3), 648-653.

2. Dankowska E., Bendowska J. 2006. Further studies on the effect of plant infusions on the feeding of Deroceras leave (O.F. Müller, 1774). Folia Malacol., 14, 57-60.

3. Deletre E., Maelle M., Chantal M., Fabrice C., Thibaud M. 2015. Behavioral response of Bemisia tabaci (Hemiptera: Aleyrodidae) to 20 plant extracts. J. Econ. Entomol. 108(4), 1890-1901.

4. Ebadollahi A. 2011. Susceptibility of two sitophilus species (Coleoptera: Curculionidae) to essential oils from Foeniculum vulgare and Satureja hortensis. Ecologia Balkanica, 3(2), 1-8.

5. Gniewosz M., Synowiec A., Dyrda M., Kuczerenko A., Przybył J., Węglarz Z. 2009. Właściwosci przeciwbakteryjne filmu pollulanowego wzbogaconego w ekstrakt z cząbru górskiego (Satureja montana). Bromat. Chem. Toksykol., XLII, 3, 985-989.

6. Hansen L.M., Lorentsen L., Boelt B. 2007. How to reduce the incidence of black bean aphids (Aphis fabae Scop.) attacking organic growing field beans (Vicia faba L.) by growing partially resistant bean varieties and by intercropping field beans with cereals. Acta Agr. Scand. B - S.P. 58(4), 359-364.

7. Lamparski R. Wawrzyniak M. 2004. Effect of water extracts from Gerniaceae (Geraniaceae) plants on feeding and development of Colorado potato beetle (Leptinotarsa decemlineata Say). EJPAU, 7(2).

8. Maedeh M., Hamzeh I., Hossein D., Majid A., Reza R.K. 2011. Bioactivity of essential oil from Sat- 
ureja hortensis (Laminaceae) against three storedproduct insect species. AJB, 10(34), 6620-6627.

9. Nauen R., Denholm I. 2005. Resistance of insect pests to neonicotinoid insecticides current status and future prospects. Arch. Insect. Biochem. 58, 2000-2015.

10. Nottingham S.F., Hardie J., Dawson G.W., Hick A.J., Pickett J.A., Wadhams L.J., Woodcock C.M. 1991. Behavioral and electrophysiological responses of Aphids to host and nonhost plant volatiles. J. Chem. Ecol., 17(6), 1231-1242.

11. Olasupo N.A., Fitygerald D.J., Gasson M.J., Narbad A. 2003. Activity of natural antimicrobial compounds against Escherichia coli and Salmonella enterica serovar Typhimurium. Lett. Appl. Microbiol., 36, 448-451.

12. Picard I., Hollingsworth R.G., Salmieri S., Lacroix M. 2012. Repellency of essential oils to Frankliniella occidentalis (Thysanoptera: Thripidae) as affected by type of oil and polymer release. J. Econ. Entomol., 105(4), 1238-1247.

13. Popović A., Šućur J., Orčić D., Štrbac P. 2013. Effects of essential oil formulations on the adult insect Tribolium castaneum (Herbst) (Col., Tenebrionidae). JCEA, 14(2), 659-671.

14. Raymond V., Barbehenn C., Constabel P. 2011. Tannins in plant-herbivore interactions. Phytochemistry, 72(13), 1551-1565.

15. Serrano C., Matos O., Teixeira B., Ramos C., Neng N., Nogueira J., Nunes M.L., Marques A. 2011. Antioxidant and antimicrobial activity of Sature- ja montana L. extracts. J. Sci. Food Agr. 91(9), 1554-1560.

16. Shannag H.K. 2007. Effect of black bean aphid, Aphis fabae, on transpiration, stomatal conductance and crude protein content of faba bean. Ann. Appl. Biol. 151(2), 183-188.

17. Silva F.V.M., Martins A., Salta J., Neng N.R., Nogueira J.M.F., Mira D., Gaspar N., Justino J., Grosso C., Urieta J.S., Palavra A.M.S., Rauter A. 2009. Phytochemical profile and anticholinesterase and antimicrobial activities of supercritical versus conventional extracts of Satureja montana. J. Agric. Food Chem. 57(24), 11557-11563.

18. Šućur J., Popović A., Petrović M., Anačkov G., Bursić V., Kiprovski B., Prvulović. 2015. Allelopathic effects and insecticidal activity of aqueous extracts of Satureja montana L. J.Serb. Chem. Soc. 80(4), 475-484.

19. Tscharntke T., Klein A. M., Kruess A., Dewenter I. S., Thies C. 2005. Landscape perspectives on agricultural intensification and biodiversity - ecosystem service management. Ecol. Letters, 8(8), 857-874.

20. Wang K.Y., Guo Q.L., Xia X.M., Wang H.Y., Liu T.X. 2007. Resistance of Aphis gossypii (Homoptera: Aphididae) to selected insecticides on cotton from five cotton production regions in Shandong, China. J. Pestic. Sci. 32(4), 372-378

21. Wawrzyniak M. 2009. Effect of extracts from Geraniaceae plants on Pieris brassicae L. JCEA 10(4), 361-365. 